\title{
MAKNA KONTRIBUSI PENDAPATAN \\ TERHADAP KESEJAHTERAAN EKONOMI KELUARGA BAGI \\ SUAMI TKW PADA RUMAH TANGGA PETANI DI DAERAH \\ SUBURBAN DESA CANDIRENGGO KABUPATEN MALANG
}

\author{
Singgih Susilo ${ }^{1}$
}

Email: singgih.susilo.fis@um.ac.id

\begin{abstract}
Abstrak: Jenis pekerjaan suami serta penghasilan yang tidak menentu dari suami menjadi salah satu penyebab istri atau wanita bekerja untuk membantu perekonomian keluarga. Selain itu tingkat pendidikan istri yang lebih tinggi menjadikan istri memutuskan untuk bekerja. Penghasilan istri yang bekerja tersebut dapat memberikan kontribusi pada pendapatan rumah tangga. Adanya istri yang bekerja diluar rumah memberikan pemahaman pada suami terkait kedudukan istri dalam rumah tangga. Tujuan dari penelitian ini yaitu untuk mengetahui konteks sosial yang melatar belakangi istri bekerja serta makna istri bagi suami dalam kehidupan berumah tangga. Hasil penelitian menunjukan bahwa konteks sosial yang melatarbelakangi pemahaman suami terhadap istri yang bekerja adalah kondisi sosial ekonomi keluarga yang mayoritas bekerja sebagai petani, serabutan, buruh dan tukang bangunan serta penghasilan suami yang tidak menentu serta pendidikan suami yaitu mayoritas SD sehingga sulit mencari pekerjaan. Sehingga mendorong istri bekerja untuk membantu perekonomian keluarga. Namun, ditemukan dilapangan beberapa istri yang bekerja dikarenakan ingin menyalurkan hobi dan memiliki kesempatan bekerja padahal suami dapat mencukupi kebutuhan rumah tangga. Adapun istri bekerja karena keterbatasan ekonomi dan memiliki kesempatan kerja merupakan motif sebab (because motive) dan penghasilan istri di luar rumah serta kesenangan istri menjadi motif tujuan (in order to motive). Suami memaknai istri yang bekerja di luar rumah sebagai 1) sumber ekonomi keluarga, 2) pekerja , dan 3) istri bekerja dipahami sebagai teman hidup.
\end{abstract}

Kata Kunci : Makna, Suami, Istri, Rumah tangga.

\section{PENDAHULUAN}

Fenomena yang muncul di daerah pedesaan menunjukkan adanya norma yang kuat bahwa wanita sebagai istri atau ibu rumah tangga terlibat pula dalam pekerjaan mencari nafkah. Dengan demikian segala usaha untuk meningkatkan penghasilan wanita berarti peningkatan penghasilan rumah tangga.Sayogyo dalam Sutinah (1997) mengemukakan bahwa norma yang berlaku di sebagian besar masyarakat memandang wanita dalam rumah tangga berfungsi sebagai pencari nafkah, kemudian wanita dalam rumah tangga mempunyai kedudukan sebagai pengambil keputusan dalam urusan rumah tangga dan dalam mencari nafkah. 
Singgih Susilo. Makna Kontribusi Pendapatan Terhadap Kesejahteraan Ekonomi Keluarga Bagi Suami TKW Pada Rumah Tangga Petani Di Daerah Suburban Desa Candirenggo Kabupaten Malang

Peningkatan pendidikan wanita dan desakan kebutuhan ekonomi rumah tangga mendorong seorang wanita tersebut masuk dalam pasar tenaga kerja, untuk bekerja sehingga wanita tersebut memperoleh penghasilan. Banyaknya wanita masuk dalam status bekerja tidak hanya terjadi pada daerah perkotaan, tetapi juga terjadi di daerah pedesaan, yang sebagian besar rumah tangga bermata pencaharian disektor pertanian. Dalam perkembangannya sekarang ternyata tugas atau peranan wanita dalam kehidupan keluarga semakin berkembang lebih luas lagi (Ihromi, 1995).

Penelitian Susilo (2002; 2007) menemukan bahwa lebih dari 50 persen istri yang bekerja memberikan sumbangan penghasilan terhadap pendapatan keluarga. Makna kontribusi pendapatan terhadap kesejahteraan ekonomi keluarga bagi tenaga kerja wanita (Istri) perlu dikaji untuk mengetahui motif apa dirinya rela melakukan pekerjaan tersebut.Wanita lebih banyak mendominasi sebagai pekerja marginal, namun belakangan ini orientasi wanita yang bekerja memiliki kemandirian dalam pengelolaan keperluan dan bisa memberikan kontribusi terhadap keluarga. Tenaga kerja wanita dalam penelitian ini adalah tenaga kerja yang bekerja di berbagai sektor pada rumah tangga tani di daerah suburban Kelurahan Candirenggo, Kecamatan Singosari Kabupaten Malang.

Kelurahan Candirenggo teletak sekitar 2 km dari Singosari, masyaraktnya sebagian besar bermatapencaharian di sektor pertaniaan, letaknya yang sangat strategis dengan Singosari memberikan akses yang sangat mudah dan lancar bagi masyarakatnya untuk melakukan aktivitas. Banyaknya wanita (istri) yang melakukan pekerjaan di luar desa salah satunya tidak terlepas dari faktor mudahnya akses tersebut. Berdasarkan observasi pada jam 9 malam masih terlihat banyak warga yang baru pulang dan mau berangkat kerja, terutama mereka yang bekrja di pabrik terkait dengan kerja giliran malam. Berdasarkan data kantor desa setempat, bahwa masyaraktnya yang banyak bekerja pada sektor pertanian 304 orang, dan jumlah wanita (istri petani) yang bekerja diberbagai sektot sebanyak sebanyak 267 orang (Data Monografi Desa Candirenggo, 2014).

Dalam dunia pemaknaan (fenomenologi), makna istri yang bekerja dalam rangka membantu ekonomi rumah tangganya tidak bisa terlepas dari berbagai motif, baik motif sebab maupun motif tujuan. Seorang wanita yang bekerja memiliki beberapa faktor yang berkaitan dengan latar belakang dirinya maupun latar belakang keluarganya, sehingga mendorong dirinya untuk bekerja di luar rumah. Disisi lain seorang wanita (istri) bekerja juga tidak terlepas dari faktor faktor tarik yang ada didaerah tujuan (Hugo, 1978; Lee,1975; Mantra, 1985). Untuk menjawab permasalahan pemahaman suami terhadap istri yang bekerja diluar rumah dalam penelitian ini, maka perspektif yang digunakan adalah perspektif fenomenologi. Pendekatan fenomenologi menghendaki sejumlah interpretasi-interpretasi tersebut, sampai akhirnya dapat masuk ke dalam dunia 
makna (pemahaman) dan dunia konsep subyek penelitian (Ritzer, 2005).

Konsep fenomenologi, pertama kali dikembangkan oleh Edmund Husserl, kemudian muncul fenomenologi Alfred Schutz, dan fenomenologi Peter L. Berger (Ritzer.1996). Dari ketiganya memiliki kekhususan studi yang berbeda, namun pendekatan fenomenologi yang sesuai dengan fokus penelitian yakni tentang makna istri yang bekerja diluar rumah bagi suami adalah fenomenologi yang dikembangkan oleh Alfred Schutz yang menjelaskan suatu pemahaman tidak terlepas dari because motives dan in order to motives. Permasalahan utama yang menjadi fokus dalam penelitian ini adalah: Bagaimanakah kontek sosial keluarga istri yang bekerja di luar rumah bagaimana makna kontribusi pendapatan pada kesejahteraan ekonomi bagi suami.

\section{METODE}

Penelitian ini menggunakan perspektif fenomenologi untuk memahmi dan memaknai peran pekerjaan rumah tangga oleh suami. Perspektif fenomenologi dimaksudkan agar individu sebagai subyek penelitian dapat memberikan interpretasi. Perspektif fenomenologi yang digunakan adalah fenomenologi Albert Schutz, mengenai dunia intersubyektif dalam kehidupan sehari-hari. Schutz (1962) menyatakan bahwa dunia sosial keseharian merupakan sesuatu `yang intersubyektif. Pemahaman (dunia makna) tidak terlepas dari because motives dan in order to motives. Pemahaman menurut Schutz tidak terlepas dari konteks soaial individu (because motives).

Adapun subyek penelitian adalah seluruh suami dari istri bekerja di luar rumah. Penggalian informasi subyek menggunakan metode observasi partisipasi dan wawancara mendalam (Fatchan.A, 2009). Tahapan dalam penelitian ini adalah: (1) tahapan persiapan penelitian, (2) tahapan penelitian lapangan, (3) tahap analisis data (reduksi data, display data, dan verifikasi).

\section{HASIL DAN PEMBAHASAN}

\section{Konteks Sosial}

Kontek sosial pada keluarga wanita pekerja merupakan faktor yang menyebabkan wanita bekerja. Seperti dalam perspektif fenomenologi Alferd Schutz (1962), studi pemaknaan tidak bisa terlepas dari konteks sosial sebagai motif sebab (because motives) maupun motif tujuan (in order to motives). Alferd Schurtz menyebutkan bahwa dalam dunia pemaknaan, menelusuri konteks sosial merupakan hal yang penting dilakukan, karena motif sebaga (because motives) yang melatarbelakangi wanita bekerja tidak terlepas dari konteks sosial yang dialaminya. Maka dari itu, konteks sosial dari subjek penelitian diperlukan untuk mendapatkan informasi yang mendalam mengenai motive wanita bekerja.

Kelurahan Candirenggo merupakan salah satu kelurahan di kecamatan Singosari, yang merupakan bagian dari wilayah Kabupaten Malang, Propinsi Jawa Timur. Kelurahan Candirenggo teletak sekitar $2 \mathrm{~km}$ dari Singosari, masyaraktnya sebagian besar bermata 
Singgih Susilo. Makna Kontribusi Pendapatan Terhadap Kesejahteraan Ekonomi Keluarga Bagi Suami TKW Pada Rumah Tangga Petani Di Daerah Suburban Desa Candirenggo Kabupaten Malang

pencaharian di sektor pertaniaan, letak desa yang sangat strategis dengan Singosari memberikan akses yang sangat mudah dan lancar bagi masyarakatnya untuk melakukan aktivitas. Dengan akses yang mudah tersebut banyak dari penduduk terutama wanita yang bekerja di sektor industri, dikarenakan kebutuhan tenaga kerja pada sektor tersebut lebih banyak wanita.

Konteks sosial ekonomi yang melatarbelakangi wanita bekerja adalah ketidakmampuan ekonomi keluarga. Hal tersebut salah satunya dapat dilihat dari ukuran kondisi pekerjaan suami diantaranya petani, buruh tani, pekerja serabutan, buruh dan tukang bangunan. Pekerjaan dan penghasilan yang tidak menentu dari suami tersebut mendorong wanita untuk bekerja dan membantu perekonomian keluarga. Konteks sosial lain yang melatar belakangi istri bekerja adalah banyaknya suami yang hanya berpendidikan SD, pendidikan tersebut tidak mendukung suami untuk dapat mencari pekerjaan yang tetap. Kondisi pekerjaan suami dan rendahnya tingkat pendidikan suami serta kebutuhan ekonomi yang semakin meningkat, menjadi motif sebab suami mengijinkan istri mereka bekerja.

Berbeda halnya dengan kondisi sosial ekonomi keluarga yang sudah tercukupi oleh suami namun istri tetap bekerja diluar rumah. Hal tersebut dikarenakan sang istri memang ingin menyalurkan hobi atau tidak terbiasa diam dirumah dan memiliki kesempatan kerja sehingga hal tersebut dimanfaatkan istri untuk dapat membantu meringankan beban suami untuk memenuhi kebutuhan keluarga.

\section{Pemahaman Tenaga Kerja Wanita Bagi Suami}

Istri yang bekerja dan berkontribusi dalam perekonomian keluarga, memiliki banyak makna (meaning). Setiap subjek yang diwawancarai memiliki pemahaman yang berbeda. Pendekatan fenomenologi digunakan untuk memahami pemahaman masing-masing suami terhadap istri yang bekerja.

Mengacu pada pemahaman perpektif fenomenologi Alferd Schutz adanya motif sebab dan motif tujuan, maka suami memahami istri yang bekerja di luar rumah sebagai 1) sumber ekonomi keluarga, 2) pekerja , dan 3) istri bekerja dipahami sebagai teman hidup.

\section{a. Tenaga Kerja Wanita dipahami sebagai Sumber Ekonomi Keluarga}

Pekerjaan istri di luar rumah dipahami suami sebagai "sumber ekonomi keluarga" mengandung pengertian bahwa penghasilan istri yang bekerja menjadi sumber ekonomi untuk memenuhi kebutuhan dasar keluarga. Penghasilan istri sebagai sumber ekonomi keluarga dikemukakan oleh subyek, Pak Warimin yang mengatakan bahwa:

“...istri saya bekerja, tujuan utamanya sebagai sumber pemenuhan kebutuhan hidup sehari-hari keluarga saya termasuk membiayai sekolah anak-anak saya, sebab penghasilan saya sebagai kuli bangunan tidak tentu dapat penghasilan kalau saya ada yang mengajak bekerja, kalau tidak ada yang mengajak saya 
bekerja, saya tidak mendapatkan penghasilan, sehingga penghasilan saya sendiri tidak cukup untuk memenuhi kebutuhan hidup keluarga" (Wawancara, tanggal 8 Sepetember 2016).

Berdasarkan ungkapan Pak Warimin tersebut dapat diketahui bahwa subyek melakukan tindakan mengijinkan istri bekerja diluar rumah didorong oleh motif tujuan sebagai sumber ekonomi keluarga. Hal ini dilatarbelakangi oleh keadaan ekonomi keluarga subyek di daerah asal yang masih serba kekurangan, sehingga penghasilan dari istri yang bekerja di luar rumah oleh Subyek dimaknai sebagai sumber ekonomi keluarga

Sesuai dengan pemahaman yang dikemukanan oleh Alferd Shutz yaitu tidak terlepas dari because motive and in order motive. Pemahaman ini dilatarbelakangi (because motive) oleh konteks sosial keluarga bahwa subjek tidak punya pekerjaan dan penghasilan yang tetap sehingga istri bekerja dan adanya motif tujuan (in order to motive) penghasilan dari istri yang bekerja memang dijadian sumber ekonomi keluarga. Pemahaman Tenaga Kerja Wanita Sebagai Pekerja dipahami oleh subyek lainnya seperti Pak Dumadi, Pak Bashori dan Pak Muklison.

\section{b. Tenaga Kerja Wanita Dipahami Sebagai Pekerja}

Istri yang bekerja di luar rumah dipahami oleh suami sebagai pekerja adalah bahwa istri bekerja untuk mencari kesibukan, disamping untuk mendapatkan penghasilan. Pada pemahamnan ini suami tanpa istri bekerjapun mampu untuk memenuhi kebutuhan ekonomi sehari hari, tetapi dengan istri yang bekerja penghasilannya dapat membantu penghasilan rumah tangganya. Tenaga kerja dipahami sebagai Pekerja bahwa penghasilan tenaga kerja wanita (istri) bukan sebagai sumber utama ekonomi keluarga, tetapi dipahami sebagai bantuan ekonomi rumah tangganya. Pada kenyataannya dilapangan para suami pada pemahaman ini menyimpulkan sangat terbantu ekonomi rumah tangganya ketika istri istri mereka bekerja.

Istri bekerja sebagai pekerja dipahami oleh pak Supani salah satu petani di Desa Candirenggo. Lebih lanjut pak Supani mengungkapkan sebagai berikut:

"......Saya senang istri saya bekerja dan sangat membantu ekonomi rumah tangga, saya mengakui tanpa dibantu oleh istri yang bekerja saya sangat mampu untuk memenuhi kebutuhan hidup sehari hari rumah tangga saya, tetapi dengan dibantunya oleh istri saya yang bekerja, kebutuhan ekonomi rumah tangga saya lebih besar dan saya semakin ringan dalam menghadapi kebutuhan hidup sehari hari terutama dalam biaya sekolah anak anak......"(wawancara, 16 Oktober 2016).

Berdasarkan ungkapan Pak Supani tersebut di atas, dapat diketahui bahwa Istri yang bekerja dipahami sebagai pekerja, yang sangat membantu dirinya dalam memenuhi kebutuhan ekonomi rumah tangga. Pada pemahaman ini subyek sangat tidak mempermasalahkan dengan istrinya bekerja, artinya 
Singgih Susilo. Makna Kontribusi Pendapatan Terhadap Kesejahteraan Ekonomi Keluarga Bagi Suami TKW Pada Rumah Tangga Petani Di Daerah Suburban Desa Candirenggo Kabupaten Malang

seandainya istrinya tidak bekerja maka subyek bisa memenuhi kebutuhan ekonomi rumah tangganya.

Sesuai dengan pemahaman yang dikemukanan oleh Alferd Shutz yaitu tidak terlepas dari because motive and in order motive. Pemahaman ini dilatarbelakangi (because motive) oleh konteks sosial keluarga bahwa keluarga subyek memang sudah memiliki kecukupan dalam perekonomian atau subjek sudah bisa mencukupi kebutuhan namun sangat terbantu dengan istri yang bekerja, dan adanya motif tujuan (in order to motive) istri ingin tetap bekerja untuk mengisi waktu karena ada kesempatan kerja dan ingin membantu suami untuk mencukupi kebutuhan rumah tangga.Pemahaman Tenaga Kerja Wanita Sebagai Pekerja dipahami oleh subyek lainnya seperti Pak Khamid dan Pak Suryanto.

\section{c. Tenaga Kerja Wanita Dipahami Sebagai Teman Hidup}

Pemahaman subyek terhadap istri yang bekerja sebgai teman hidup, didasarkan pada kenyataan bahwa subyek secara ekonomi lebih dari mampu, subyek sebagai petani tetapi memiliki lahan sawah pertanian lebih dari cukup, sehingga penghasilan dari sektor pertanian sangat cukup untuk kebutuhan ekonomi keluarganya.

Pada umumnya subyek sebelum menikah sudah mapan dalam ekonomi karena memiliki warisan dari orang tuanya yang tergolong luas. Pada saat menikah rumah tangganya secara ekonomi tidak menjadi masalah, sehingga suatu ketika istri ingin bekerja atau sudah bekerja penghasilannya digunakan untuk kebutuhan pribadi istrinya. Subyek mengijinkan istrinya bekerja dengan alasan istrinya agar mempunyai kesibukan, dan istri bekerja atas keinginan dirinya sendiri. Oleh karena itu suami memahami istrinya yang bekerja tetap sebagai teman hidup. Suami sangat tidak berharap dari penghasilan istrinya, karena dirinya lebih dari bisa untuk memenuhi kebutuhan ekonomi keluarganya.

Ungkapan pemahaman tersebut dikemukakan oleh beberapa subyek, salah satunya oleh Amat Santoso sebagai berikut:

..."Sebelum menikah istri saya sudah bekerja menjadi perawat, dan sayapun juga sudah bekerja menekuni bertani sawah dari warisan orang tua. Sebelum menikah istri sudah memiliki penghasilan dan saya juga sudah memiliki penghasilan, sehingga ketika menikah kami hanya tinggal mengatur manajemen rumah tangga, dan kesepakatan kami yang mengelola dan mengatur ekonomi rumah tangga adalah istri, sehingga ketika saya mendapatkan penghasilan saya berikan pada istri. Oleh karena itu saya dengan istri seperti teman hidup dalam berumah tangga,...." (Wawancara, 16 Oktober 2016).

Berdasarkan pernyataan Santoso ternyata istrinya sudah bekerja sebelum menikah dan sudah memiliki penghasilan sendiri, sementara subjek sudah menekuni pertanian yang diwariskan oleh 
orang tuanya. Keduanya sepakat mengatur menajemen rumah tangga oleh istri, subjek menghormati istri sehingga hasil dari bertani semua dikelola oleh istri.

Pemahaman ini sejalan dengan yang dikemukakan oleh Alferd Shutz bahwa dalam fenomenologi, dunian pemahaman tidak terlepas dari because motive dan in order motive. Pemahaman ini dilatarbelakangi (konteks sosial) bahwa keluarga subjek memang sudah memiliki kecukupan dalam perekonomian dan adanya motif tujuan (in order to motive) istri ingin tetap bekerja untuk mengisi waktu dan memang sudah menjadi hobi atau kewajiban. Pemahaman Tenaga Kerja Wanita Sebagai Teman Hidup dipahami oleh subyek lainnya seperti Pak Ngatuji, dan Pak Na'em.

\section{KESIMPULAN}

Konteks yang melatarbelakangi Kelurahan Candirenggo sebagai darerah penelitian adalah lokasinya yang sangat strategis dengan Singosari memberikan akses yang sangat mudah dan lancar bagi masyarakatnya untuk melakukan aktivitas. Dengan akses yang mudah tersebut banyak dari penduduk terutama wanita yang bekerja di sektor industri, dikarenakan kebutuhan tenaga kerja lebih banyak wanita. Banyaknya suami yang bekerja disektor pertanian dan bangunan seta memiliki pendidikan yang rendah menyebabkan penghasilan suami tidak menentu dan mendorong istri bekerja untuk membantu perekonomian keluarga, hal merupakan salah satu fungsi wanita (sumber ekonomi keluarga). Selain itu pendidikan istri dan kesempatan kerja bagi wanita menjadi penyebab wanita bekerja. Konteks ini merupakan salah satu motif sebab (because motive), subyek mengijinkan istri mereka bekerja, dengan penghasilan istri dan kepuasan istri menjaditujuannya (in oerder to motive). Mengacu pada pemahaman perpektif fenomenologi Alferd Schutz (1962), maka pemahaman-pemahan istri yang bekerja diluar rumah oleh suami memberikan gambaran adanya pola-pola pemahaman sebagai berikut: 1) sumber ekonomi keluarga, 2) pekerja , dan 3) istri bekerja dipahami sebagai teman hidup.

\section{DAFTAR PUSTAKA}

Berger, Peter. L. 1967. The Sacred Canopy: Elements of a Sociological Theory of Religion. Garden City. New York: Anchor Books.

Fatchan,A. 2009. Metode Penelitian Kualitatif. Malang: Jenggala Pustaka Utama.

Hugo, Graeme, J.1978. Population Mobility in West Java. Yogyakarta: Gadjah Mada University Press.

Ihromi,dkk, 1995. Kisah Kehidupan Wanita untuk Mempertahankan Kelestarian Ekonomi Rumah Tangga, Kajian terhadap Wanita Golongan Penghasilan Rendah Menengah. Jakarta: Fakultas Ekonomi, UI.

Kantor Keluarahan Candirenggo. 2014. Data Monografi Keluarahan Candirenggo.

Lee, Everett S. 1975. Suatu Teori Migrasi. Seri Terjemahan No 3. Yogyakarta: Pusat Penelitian Studi Kependudukan UGM.

Mantra, I.B. 1985. Pengantar Studi Demografi. Yogyakarta: Nur Cahaya. 
Singgih Susilo. Makna Kontribusi Pendapatan Terhadap Kesejahteraan Ekonomi Keluarga Bagi Suami TKW Pada Rumah Tangga Petani Di Daerah Suburban Desa Candirenggo Kabupaten Malang

Ritzer,George, 1996. Sosiological Theory, Fourt Edition. New York: The McGraw-Hill Companies, Inc.

Ritzer G, dan Goodman, D. 2005. Teori Sosiologi Modern. Jakarta: Prenada Media.

Schutz, Alfred. 1962. Collected Papers I: The Problem of Social Reality. Maurice Natanson, ed. The Hague: Nijhoff.

Susilo, Singgih. 2002. Remitansi dan Kesejahteraan Keluarga (Hubungan Antara Besarnya Remitansi dan Tingkat Kesejahteraan
Keluarga di Daerah Asal, Suatu Kasus TKI di Desa Dungmanten Kecamatan Rejotangan Kabupaten Tulungagung. Tesis Pasca Sarjana UNAIR Surabaya.

\section{Perebutan Lahan}

Kerja Wanita Pada Industri Rumah Tangga Di Kabupaten Malang: Suatu Kajian Gender. Malang: LP2M UM (tidak diterbitkan).

Sutinah, 1997. Kerja Rumahan Di Kabupaten Gresik. Surabaya: Lembaga Penelitian Universitas Airlangga. 